ECCOMAS

Proceedia
COMPDYN 2021

$8^{\text {th }}$ ECCOMAS Thematic Conference on Computational Methods in Structural Dynamics and Earthquake Engineering

M. Papadrakakis, M. Fragiadakis (eds.)

\title{
SEISMIC STRENGTHENING OF EXISTING URM STRUCTURES THROUGH CLT ELEMENTS: NUMERICAL ANALYSIS OF THE APPLICATION OF A NOVEL INTERVENTION TECHNIQUE
}

\author{
M. Salvalaggio ${ }^{1}$, M. Pegoraro ${ }^{1}$, E. Saler ${ }^{2}$, U. Turrini ${ }^{3}$ and M.R. Valluzzi ${ }^{1}$ \\ ${ }^{1}$ Department of Cultural Heritage, University of Padova \\ Piazza Capitaniato 7, 35139 Padova, Italy \\ matteo.salvalaggio@unipd.it,marco.pegoraro@dicea.unipd.it, mariarosa.valluzzi@unipd.it \\ ${ }^{2}$ Department of Geosciences, University of Padova \\ via Gradenigo 6, 35131 Padova, Italy \\ elisa.saler@unipd.it \\ ${ }^{3}$ Department of Civil, Environmental and Architectural Engineering, University of Padova \\ via Marzolo 9, 35131 Padova, Italy \\ umberto.turrini@unipd.it
}

\begin{abstract}
The retrofit of existing masonry buildings plays a relevant role in the Italian building context, both for preservation and requalification of the cultural and architectural heritage. Historically, timber has been widely used in unreinforced masonry (URM) buildings, mainly for horizontal structures. In recent years, the use of timber in the retrofit of existing buildings has gained an increasing interest for the improvements of both structural and energetic performances. Indeed, wooden elements present good hygrothermal properties and, thanks to their lightweight and stiffness, they are suitable for the seismic improvement of masonry buildings. The aim of this paper is to numerically investigate the seismic strengthening of existing URM structures by means of cross laminated timber (CLT) panels, evaluating the coupling degree of the timber-masonry integrated system. The investigation was carried out through a finite element modelling. First a parametric local model of a CLT-masonry coupled wall was calibrated with literature experimental data. Then, the study was extended to a XVII-century URM building located in the Italian Alpine region (Roana, Vicenza province). Non-linear static analyses were carried out in order to assess the local and global behavior of the URM-CLT system and its potential benefits. Results suggested a seismic capacity improvement due to shear strength increase and global weight reduction.
\end{abstract}

Keywords: masonry building, CLT, seismic retrofitting, integrated intervention technique, FEM. 


\section{INTRODUCTION}

The seismic retrofit of existing buildings has gained more and more interest in the Italian context due to the necessity of protecting the cultural and architectural heritage. The great variability of the building typologies and the sustainability requirements lead to the necessity of finding alternative solutions to invasive interventions. As a matter of fact, massive replacements of the wooden floors with RC elements, insertion of RC curbs, etc., within unreinforced masonry (URM) buildings aimed at activating an ideal 'box-like behavior', proved to be damaging, by excessively weighing down the structure and leading to local collapses of vulnerable portions of the buildings [1].

These observations led to the need for a more accurate study on the effects of the interventions and the search for innovative methods. Timber structural elements, which were historically used in masonry buildings even for seismic purposes [2][3], present favorable characteristics for some of the problems that characterize conventional reinforcement interventions, such as reduced weight, which permits widespread intervention in the structure with a limited variation of the total seismic mass, and good mechanical properties, often more compatible with URM historical structures. Furthermore, the rapidly evolving of timber technology in recent decades developed more efficient materials, e.g., Cross Laminated Timber CLT, widening its application field and possibilities.

The intervention described in this paper is addressed to existing URM buildings which need an improvement in terms of structural-seismic capacity, functionality and energetic performances. Based on the effectiveness of URM-CLT coupling walls for shear capacity [4][5] and energetic performances improvement [6], such as the benefits of stiffened timber diaphragms [7][8], an integrated intervention aimed at the insertion of a CLT endoskeleton within a URM structure was designed.

The intervention consists in inserting a CLT structure inside the perimeter walls, substituting the un-strengthened existing floors and inner partitions and assembling a inner core able to bear part of the static and eventual seismic loads. The paper presents the procedure implemented to simulate the intervention. First, a coupled URM-CLT wall was modeled within finite element (FE) software (i.e., DIANA FEA [8]): the model was validated through the comparison with literature studies [10][11] and the influence of FEM parameters involved in the system were evaluated. Following, global models of an existing URM structure and the proposed integrated CLT-URM were created. The CLT nest was designed through a specific software for timber structures ([12]), defining the structural properties such as panel thickness and connection types. Modal and non-linear static analyses were performed, and the results compared.

\subsection{State of Art}

The CLT technology consists of layered panels of solid timber, in which each layer is oriented perpendicular to adjacent ones. This configuration permits the use of the material for the realization of large boards that can be used for both wall and floor elements, being able to bear both in-plane and out-of-plane loads. Those characteristics make the CLT an efficient and versatile element, which use has spread largely in recent years. CLT products are widely used for new buildings, but in recent years are also gaining attention for the retrofit of existing buildings [4][10][13][14].

One of the most acknowledged intervention consists in coupling CLT panels to masonry walls, thus providing benefits on structural, energetical and architectural fields [6][15]. In this 
framework, two main approaches can be adopted, depending on the location of CLT reinforcement panels, at the exterior or interior of walls [4][14], as shown in Figure 1.

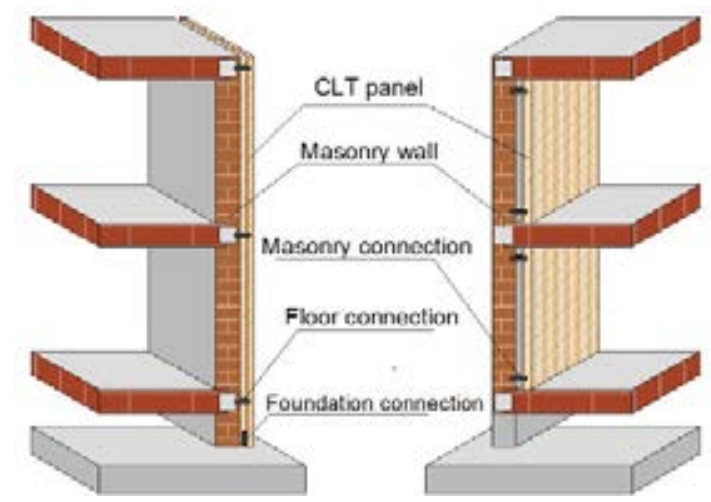

Figure 1: Approaches for CLT intervention on existing structures [6]

Particular attention has to be paid to connection systems among the existing structure and CLT elements. Different approaches can be adopted, such as connection at floor levels, taking advantage of existing RC curbs [14], or distributed URM-to-CLT connections realized with screwed joints [16]. The connection system plays a crucial role in the intervention, having to transmit actions from one system to the other and to provide ductility and resistance. However, studies proved that coupling at floors levels, without specific URM-CLT diffused connectors, is enough for shear and displacement capacities improvement of a URM wall [4].

\subsection{Case Study}

The case-study belongs to a building system known as "Cattedra", rised in Canove di Roana (Vicenza), in the North-East Italian Alps. The intervention is limited to this original building which dates back to the XVII century. It's a three-story building with a rectangular plan $(10 \mathrm{~m} \times 13 \mathrm{~m})$ (Figure 2). The structure is composed of stone masonry (SB) walls in the lower section, and hollow clay brick (HCB) masonry in the upper one (due to an elevation intervention), while floor and roof structures are RC based.

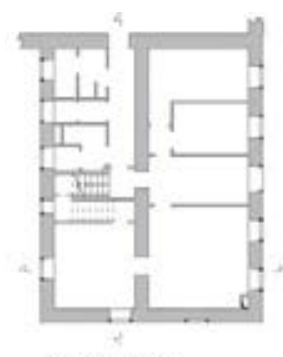

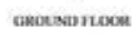

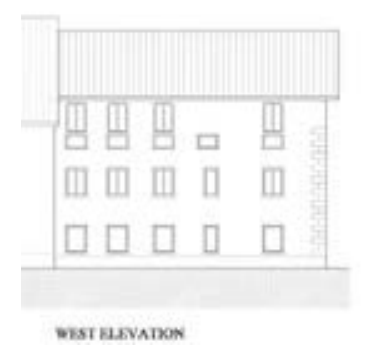

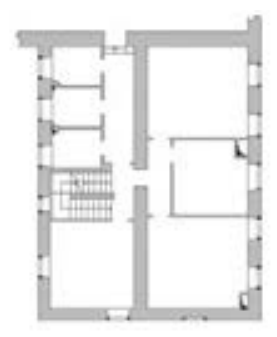

Iasrinoce

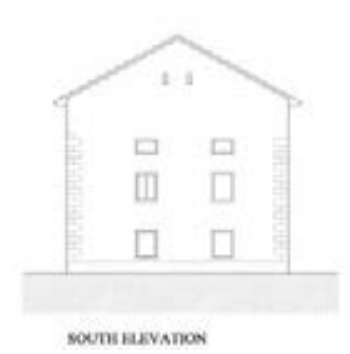

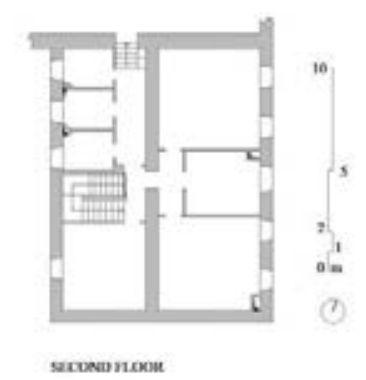

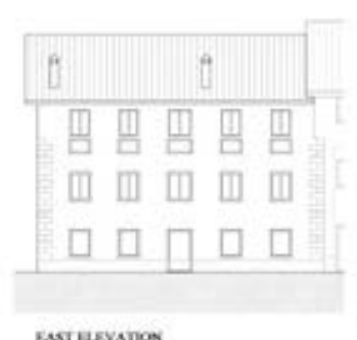

Essresvanor

Figure 2: Plans and elevations of the case study. 
The intervention concerned the upper stories of the building, excluding the first floor, due to the toned of preserving the existing conditions at this level (Figure 3). Indeed, the intervention consisted of removing the existing floors and roof structures and inserting a CLT nest, connected with the existing URM structure at floor levels. No direct connections were provided between CLT panels and URM walls.

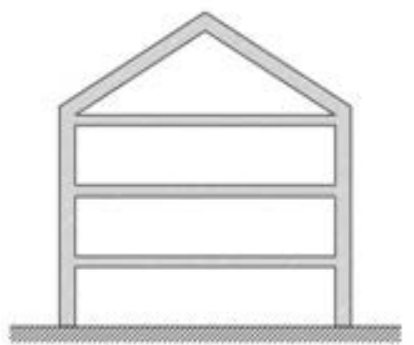

[a]

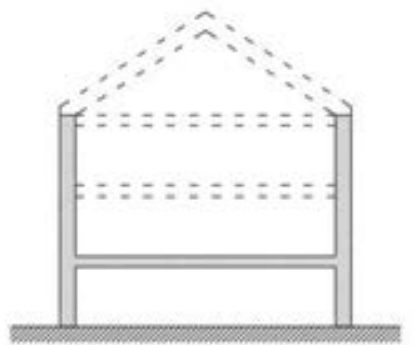

[b]

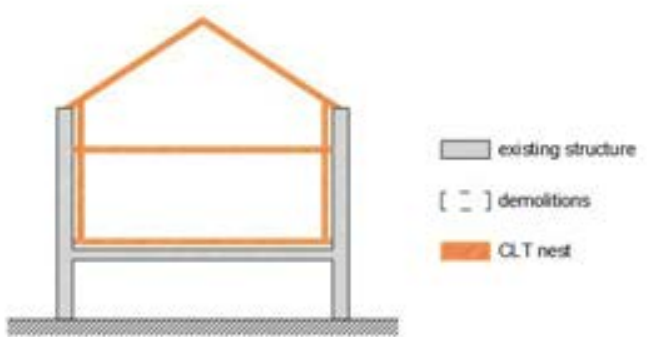

[c]

Figure 3: Intervention scheme: a) existing structure, b) demolished parts, c) new CLT nesting structure.

\section{COUPLED WALL SIMULATION}

The FE modeling of the global structure had to be preceded by the study of a local model, consisting of a $40 \mathrm{~cm}$-thick masonry wall retrofitted with three $6 \mathrm{~cm}$-thick CLT panels (Figure 4). The model was compared and validated with a literature example provided by [10], since the same FE code was used and later subjected to a parametric analysis involving both masonry and CLT systems.

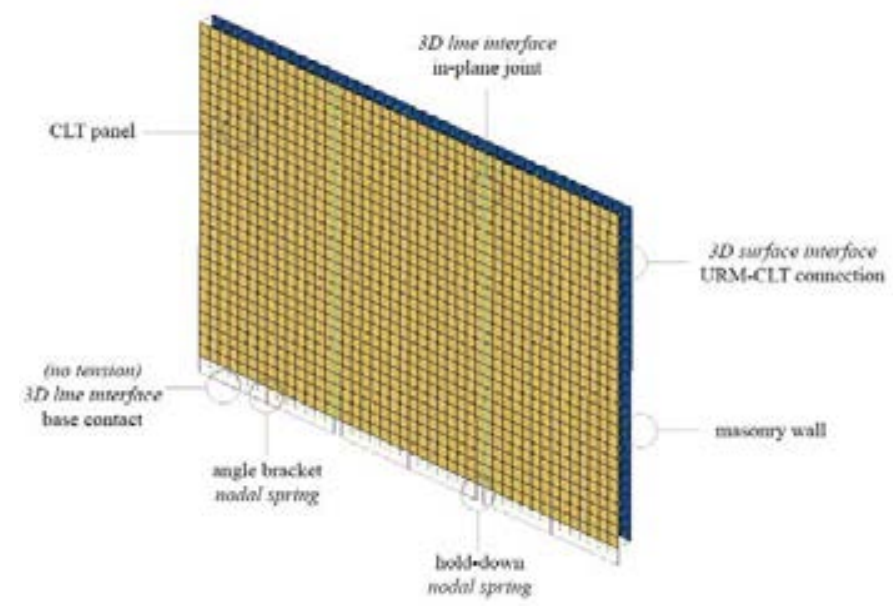

Figure 4: Local FEM model for URM-CLT interaction

\subsection{Model Generation}

The FEM model was realized with DIANA FEA software [8]. The masonry panel was modeled with 4-noded quadrilateral linear flat shell elements: a macro-modeling approach for material behavior was implemented, and units and mortar properties were merged into a continuum homogeneous material [17]. Physical non-linearities follow the smeared crack approach (Total Strain Based Crack in DIANA), in which tensile and compressive behaviors are described by stress-strain curves. Specifically, a linear softening behavior in tension and a parabolic behavior in compression were chosen. CLT panels were modeled with 4-noded quadrilateral linear curved shell. The layered structure of CLT was simplified into a homoge- 
neous linear orthotropic material, which elastic properties were calculated according to the analytical approach for composite sections suggested by Eurocode 5 [18]. Table 1 reports the material parameters.

\begin{tabular}{|c|c|c|c|}
\hline \multicolumn{2}{|r|}{ Masonry } & \multicolumn{2}{|c|}{ CLT } \\
\hline \multicolumn{2}{|c|}{ Elastic Properties } & \multicolumn{2}{|c|}{ Material Properties } \\
\hline $\mathrm{E}$ & $2500 \mathrm{MPa}$ & $\mathrm{E}_{\mathrm{x}}$ & $9000 \mathrm{MPa}$ \\
\hline$v$ & 0.25 & $\mathrm{E}_{\mathrm{y}}$ & $4500 \mathrm{MPa}$ \\
\hline WURM $_{\text {UR }}$ & $14 \mathrm{kN} / \mathrm{m}^{3}$ & $\mathrm{E}_{\mathrm{z}}$ & $1000 \mathrm{MPa}$ \\
\hline \multicolumn{2}{|c|}{ Total Strain Parameters } & $\mathrm{G}_{\mathrm{xy}}$ & $821 \mathrm{MPa}$ \\
\hline $\mathrm{f}_{\mathrm{t}}$ & $0.01 \mathrm{MPa}$ & $\mathrm{G}_{\mathrm{xz}}$ & $370 \mathrm{MPa}$ \\
\hline $\mathrm{G}_{\mathrm{t}}$ & $0.00135 \mathrm{~N} / \mathrm{mm}$ & $\mathrm{G}_{\mathrm{yz}}$ & $121 \mathrm{MPa}$ \\
\hline$f_{c}$ & $3 \mathrm{MPa}$ & & \\
\hline $\mathrm{G}_{\mathrm{c}}$ & $4.8 \mathrm{~N} / \mathrm{mm}$ & & \\
\hline$\beta$ & 0.01 & $\mathrm{~W}_{\mathrm{CLT}}$ & $4.5 \mathrm{kN} / \mathrm{m}^{3}$ \\
\hline
\end{tabular}

Table 1: FEM parameters for masonry and CLT material models (Young's and shear moduli E and G, Poisson's ratio $v$, specific weight $W$, compressive and tensile strength $f_{c}$ and $f_{t}$, compressive and tensile fracture energy $G_{c}$ and $\mathrm{G}_{\mathrm{t}}$, shear retention factor $\beta$ ).

The panels were externally connected via nodal springs, which represent the tension and shear connections (i.e., hold-down and angle bracket), while 3D line interface elements were introduced to simulate in-plane joints between panels. The CLT panels were connected to the URM wall through 3D surface interface elements. At last, a no-tension non-linear 3D line interface element was modeled, which represents the contact interactions at the base of the panel; this was to simulate base compression and neglect tensile retention during shear loads. Table 2 shows the FE parameters implemented for the connection elements.

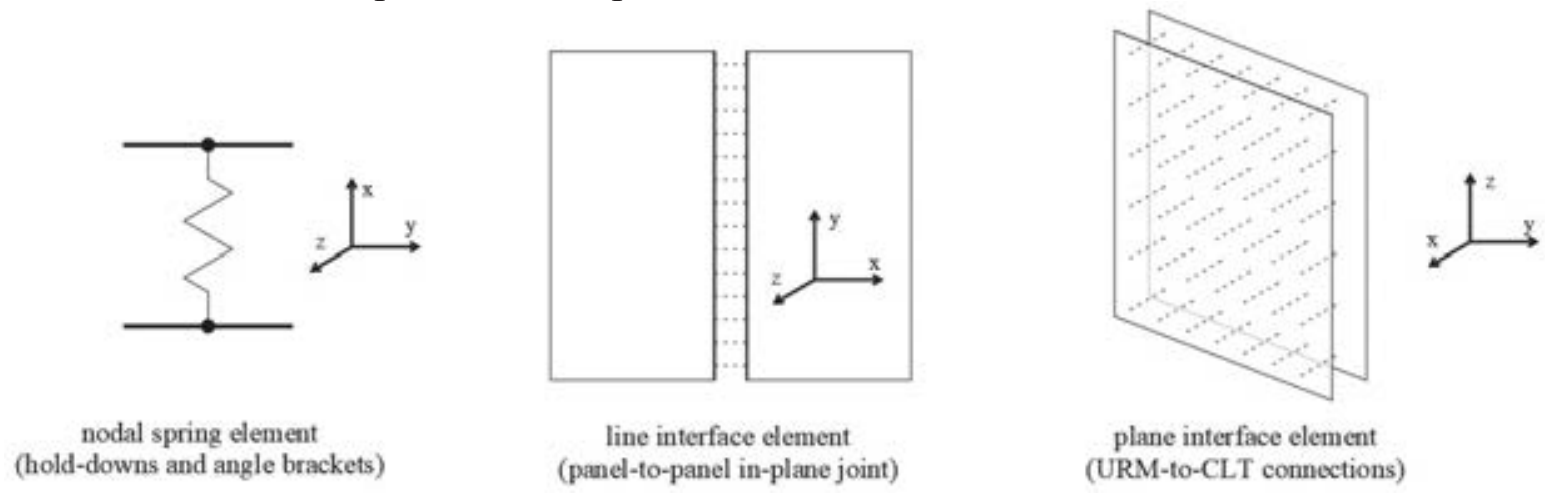

Figure 5: Local reference axes for connection elements in FE model.

\begin{tabular}{lcccc}
\hline Connection & Typology & $\mathrm{k}_{\mathrm{s}, \mathrm{x}}[\mathrm{N} / \mathrm{mm}]$ & $\mathrm{k}_{\mathrm{s}, \mathrm{y}}[\mathrm{N} / \mathrm{mm}]$ & $\mathrm{k}_{\mathrm{s}, \mathrm{z}}[\mathrm{N} / \mathrm{mm}]$ \\
\hline Hold-down & nodal spring & 50000 & 0 & 0 \\
Angle brackets & nodal spring & 0 & 50000 & 50000 \\
\hline \hline & & $\mathrm{k}_{\mathrm{i}, \mathrm{x}}\left[\mathrm{N} / \mathrm{mm}^{3}\right]$ & $\mathrm{k}_{\mathrm{i}, \mathrm{y}}\left[\mathrm{N} / \mathrm{mm}^{3}\right]$ & $\mathrm{k}_{\mathrm{i}, \mathrm{z}}\left[\mathrm{N} / \mathrm{mm}^{3}\right]$ \\
\hline \hline in-plane joints & 3D line interface & 10 & 0.16 & 0.16 \\
\hline \hline URM-CLT connection & 3 D surface interface & 1 & 0.05 & 0.05 \\
\hline \hline
\end{tabular}

Table 2: FEM parameters for connections: linear spring stiffness $\mathrm{k}_{\mathrm{s}}$ and interface stiffness $\mathrm{k}_{\mathrm{i}}$ along $\mathrm{x}, \mathrm{y}$ and $\mathrm{z}$ local axes [4]. 
Pushover analyses were carried out on the URM wall and on the coupled one to evaluate the in-plane response of both systems.

By comparing the capacity curves (Figure 6), no significant differences can be noticed on the elastic branch [4]; this suggests that, in this phase, the response of the reinforced system was still determined by the masonry characteristics. When cracking occurred, an increase both in post-elastic stiffness (and consequently maximum shear) and in the ultimate displacement capacity was observed in the coupled model. These results suggest that the CLT system is more effective in the masonry damaged conditions, leading to a significant increase of system ductility (almost doubled with the CLT panels reinforcement).

The capacity curves compared to the ones provided by the reference case resulted in a good match both in terms of maximum shear resistance and ultimate displacement capacity was detected.

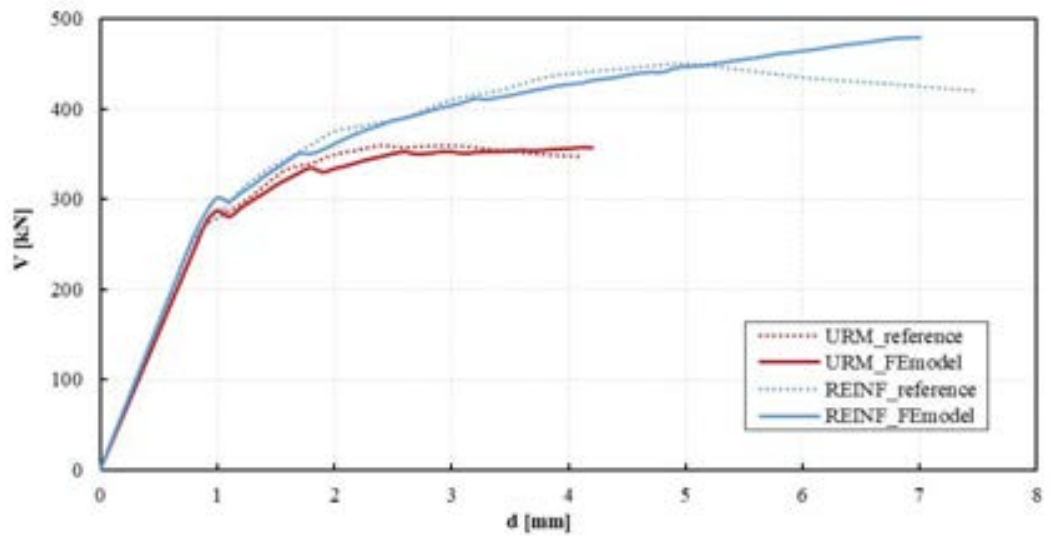

Figure 6: Comparison between FE models of URM and retrofitted walls compared to Giongo et al. [4]

\subsection{Parametric Study}

A parametric study was performed to assess input parameters and evaluate the incidence of various characteristics on the wall behavior. The investigated parameters involved both masonry and CLT systems, starting from the reference values used in the previously described model. In the Total Stain Based Crack model used for masonry, the main uncertainties concern tensile and compressive energy fracture and shear behavior (rotating crack and fixed crack models); therefore, these parameters were taken in account for the parametric analyses carried out on the URM model (Table 3), which led to the analysis of 9 cases.

\begin{tabular}{|c|c|c|c|c|c|}
\hline & & & 1 & 2 & 3 \\
\hline \multirow{3}{*}{ Parameter } & $\mathrm{G}_{\mathrm{t}}[\mathrm{N} / \mathrm{mm}]$ & GT & 0.012 & 0.005 & 0.00135 \\
\hline & $\mathrm{G}_{\mathrm{c}}[\mathrm{N} / \mathrm{mm}]$ & GC & 4.8 & 3.6 & 2.5 \\
\hline & Shear behavior & $\mathbf{S}$ & rotating & $\begin{array}{c}\text { fixed } \\
\beta=0.01\end{array}$ & $\begin{array}{c}\text { fixed } \\
\beta=0.05\end{array}$ \\
\hline
\end{tabular}

Table 3: Parameters for masonry analyses. Reference parameters cells, used for the previously validated model, are filled in grey.

The obtained pushover curves (Figure 7) revealed that the $G_{c}$ parameter had low impact on global behavior, presumably because compressive strength of masonry is way higher than tensile one, which play the major role in shear failure. The differences observed for $\mathrm{G}_{t}$ parameter are more evident, as a higher value provided a much higher displacement capacity $(+71 \%$ on the reference one). An even major influence was noticed for the shear behavior. In particular, 
rotating crack model provided a higher ideal yielding point and, consequently, higher shear resistance, while the two fixed crack model curves presented equal elastic branch. However, the higher shear retention factor $\beta$ led to both higher post-elastic stiffness and ultimate displacement values.
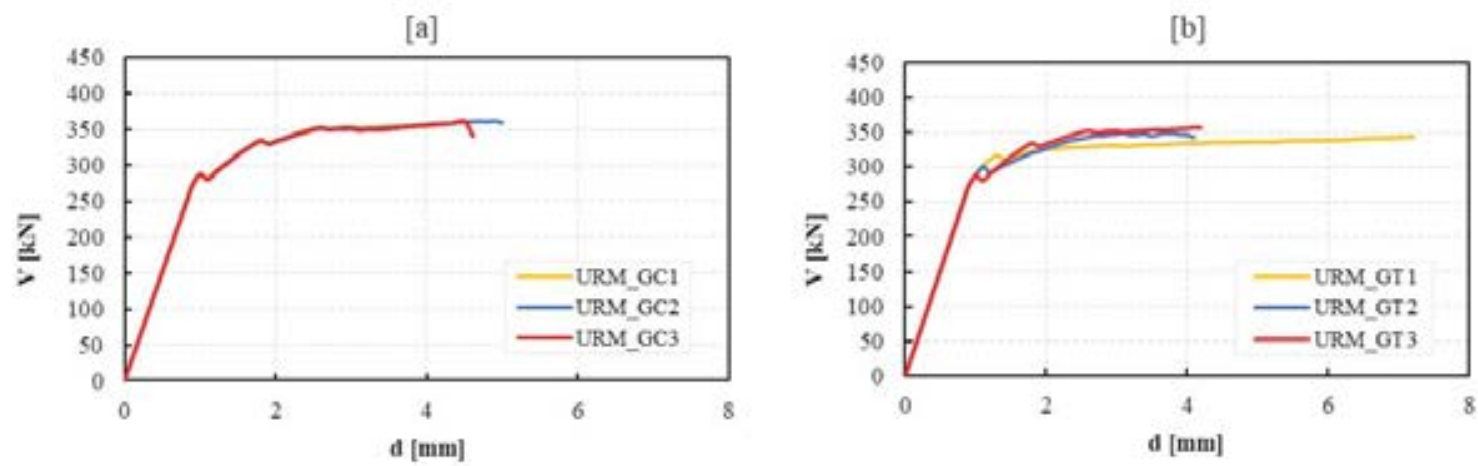

[c]

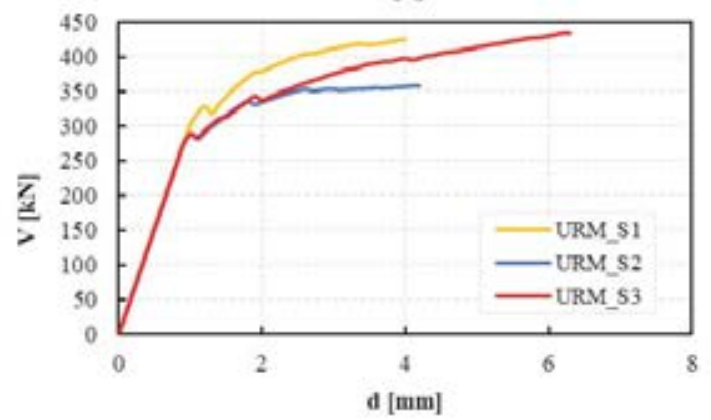

Figure 7: Pushover curves by variation of a) compressive fracture energy $G_{c}, b$ ) tensile fracture energy $G_{t}$, and $c$ ) shear behavior model

The parameters of the CLT system, i.e., hold-down stiffness, in-plane joints stiffness and panel's thickness (Table 4), were evaluated through 9 cases on the reinforced model.

\begin{tabular}{cc|c|c|c|c|}
\cline { 3 - 6 } & \multicolumn{2}{c}{} & $\mathbf{1}$ & $\mathbf{2}$ & $\mathbf{3}$ \\
\hline \multirow{3}{*}{ Parameter } & ${\text { HD } \mathrm{k}_{\mathrm{s}, \mathrm{x}}[\mathrm{N} / \mathrm{mm}]}$ & HD & 10000 & 20000 & 50000 \\
\cline { 2 - 6 } & in-plane $\mathrm{k}_{\mathrm{i}, \mathrm{y}}\left[\mathrm{N} / \mathrm{mm}^{3}\right]$ & $\mathbf{K}$ & 0.05 & 0.16 & 1.5 \\
\cline { 2 - 6 } & panel thickness $[\mathrm{mm}]$ & $\mathbf{T}$ & 60 & 90 & 140 \\
\hline
\end{tabular}

Table 4: Parameters for CLT system. Reference parameters cells, used for the previously validate model, are filled in grey.

By comparing the obtained capacity curves (Figure 8), small dissimilarities can be noticed by changing connection type, as both for hold-downs and in-plane joints, with slightly higher shear values reached by the system as elements' stiffness increases. However, differences are not very significant, which suggest that relevant improvements could be achieved by intervening on both connection systems. No major differences were observed with the variation of CLT panel thickness, since the shear behavior of the panel is still ruled by connections in the range of the measured displacements. 
[a]

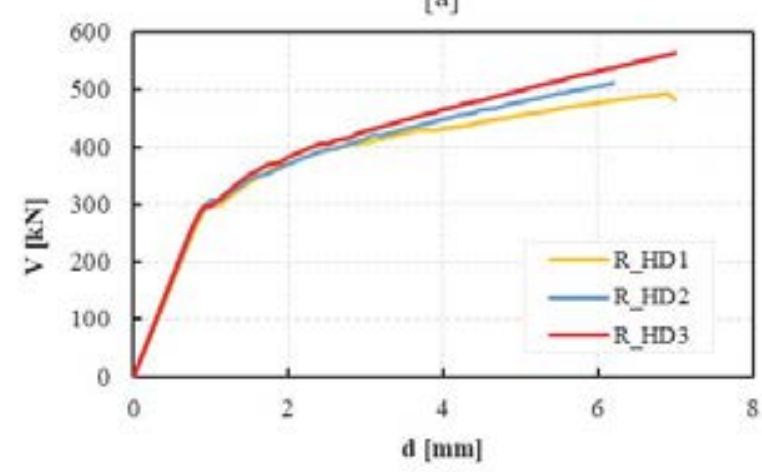

[b]

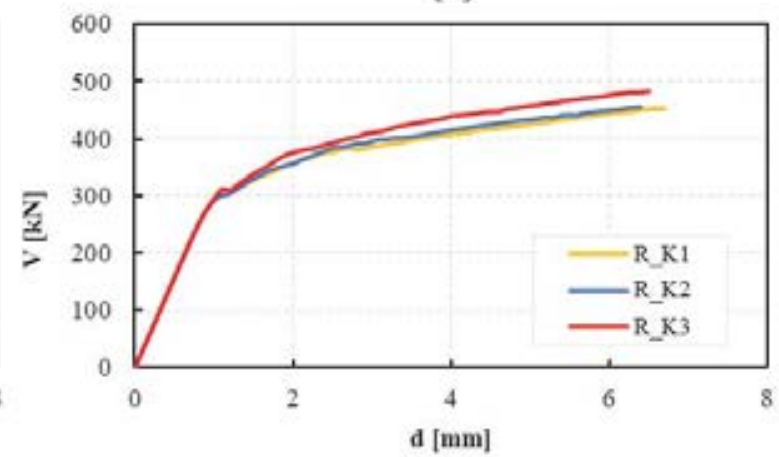

[c]

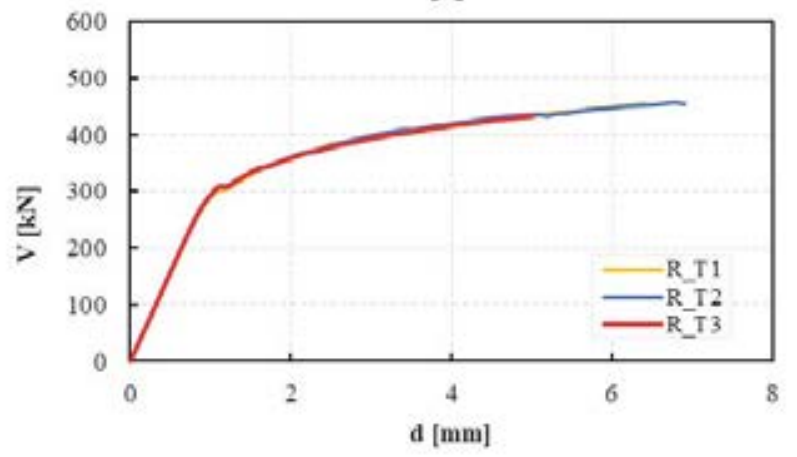

Figure 8: Pushover curves by variation of a) hold-down stiffness, b) in-plane joints stiffness, and c) panel's thickness.

\section{MODELING OF THE INTEGRATED INTERVENTION}

The extension of the local simulation to a real-scale structure was carried out by assessing a URM case study and then its retrofitted configuration with the endoskeleton integrated solution. FE models within DIANA FEA environment were generated, preceded by the preliminary design and dimensioning of the CLT inner structure.

\subsection{Preliminary design of CLT nest}

The internal CLT nest was sized by the means of TimberTech Buildings software [12], by assuming the CLT nest as independent from the URM structure. The numerical model was based on the definition of a macro-element for CLT system, which considers the different contributions in deformation and resistance provided by panels and connection elements. The software allows to easily design the structure through pre-defined elements and to verify it by means of linear static and dynamic analyses, for both vertical and horizontal loads. The process led to the definition of three-layered $10 \mathrm{~cm}$ panels for walls and five-layered $14 \mathrm{~cm}$ and $16 \mathrm{~cm}$ panels for the first and the second floor, respectively. Table 5 reports the details of the panels' types.

\begin{tabular}{ccccc}
\hline Element & Material & $\begin{array}{c}\text { n. of } \\
\text { layers }\end{array}$ & Thickness [mm] & $\begin{array}{c}\text { Layers' thickness } \\
{[\mathrm{mm}]}\end{array}$ \\
\hline Walls & Spruce C24 & 3 & 100 & $30-40-30$ \\
First floor & Spruce C24 & 5 & 160 & $40-20-40-20-40$ \\
Second floor & Spruce C24 & 5 & 140 & $40-20-20-20-40$ \\
\hline
\end{tabular}

Table 5: CLT panels typology 
Tensile and shear connections were sized with reference to the most common commercial typologies. Three types of hold-down and one type of angle bracket were used (Table 6), depending on their location in the structure.

Furthermore, panels were connected through in plane joints, consisting in $6 \mathrm{~mm} \times 80 \mathrm{~mm}$ screws, spaced $150 \mathrm{~mm}$ and coupled with a $27 \mathrm{~mm}$ Laminated Veneer Lumber (LVL) board.

\begin{tabular}{cccc}
\hline Element & Typology & Connector & n. connectors \\
\hline HD340 & Hold-Down & Nail 4x60mm & 20 \\
HD440 & Hold-Down & Nail 4x60mm & 30 \\
HD540 & Hold-Down & Nail 4x60mm & 45 \\
AB240 & Angle Bracket & Nail 4x60mm & 36 \\
\hline
\end{tabular}

Table 6: Hold-down and angle brackets types.

\subsection{Global FE model generation}

The overall FE study was carried out with DIANA FEA [8]. Firstly, a URM model of the existing structure was created. As in the local model, masonry walls were modeled as 4-noded linear flat shell elements. A Total Strain Based Crack material model was chosen, which properties are reported in Table 7. Tensile and compressive strength values were obtained from the Italian seismic code [19][20] following the results of IQM (masonry quality index) analyses carried out for walls [21]. The fracture energy values were chosen by the previous local modal and from multiple values suggested by scientific literature [22], assuming a conservative low tensile fracture energy, close to the brittle behavior.

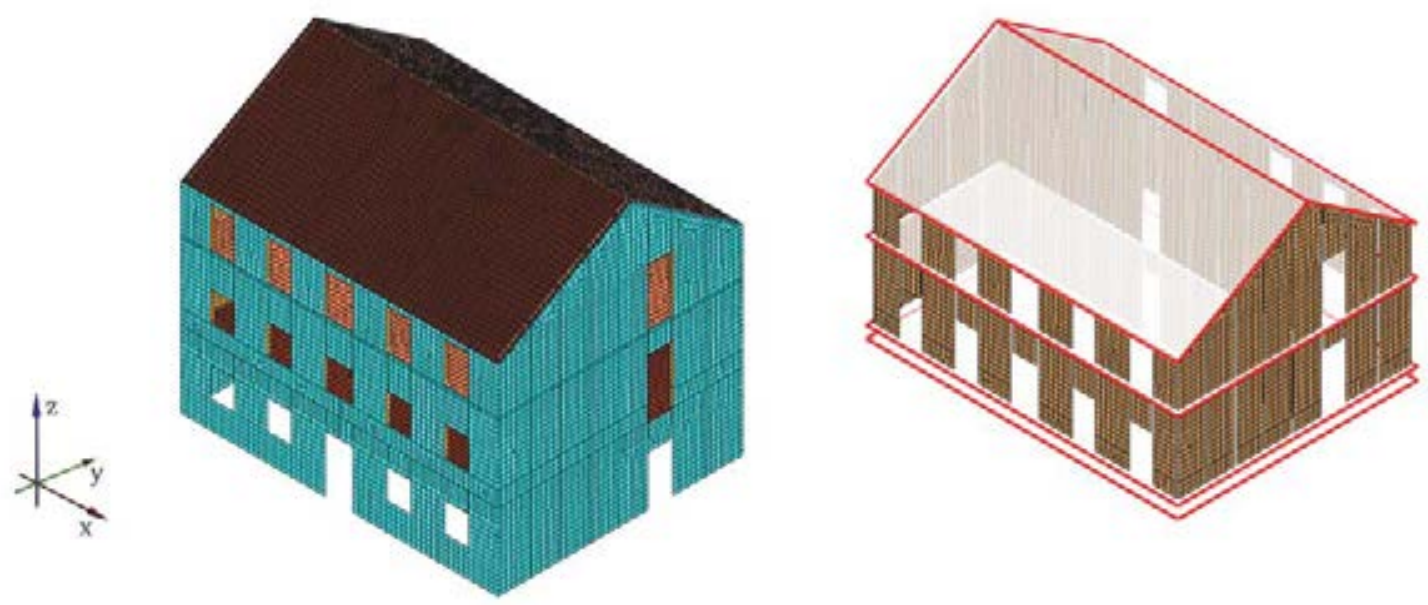

Figure 9: FEM model of a) URM building and b) CLT nest.

Masonry properties of the retrofitted model did not change since no intervention was provided for masonry, in order to assess directly the benefits of the endoskeleton addition. The CLT structure was modeled in reference to the preliminary design . CLT material properties and connection elements were the same of those of the local FE model (Table 1), i.e., nodal springs for hold-downs and angle brackets and linear interface elements for in-plane joints. 


\begin{tabular}{c|cc}
\hline \hline \multicolumn{3}{c}{ Masonry } \\
\hline \hline Parameter & SB Masonry & HCB Masonry \\
\hline $\mathrm{E}[\mathrm{MPa}]$ & 1740 & 4550 \\
$\nu$ & 0.25 & 0.25 \\
$\mathrm{w}\left[\mathrm{kN} / \mathrm{m}^{3}\right]$ & 20 & 14 \\
\hline \hline Tens. function & Linear softening & Linear softening \\
$\mathrm{f}_{\mathrm{t}}[\mathrm{MPa}]$ & 0.018 & 0.037 \\
$\mathrm{G}_{\mathrm{t}}[\mathrm{N} / \mathrm{mm}]$ & 0.00135 & 0.0045 \\
\hline \hline Comp. function & Parabolic & Parabolic \\
$\mathrm{f}_{\mathrm{c}}[\mathrm{MPa}]$ & 1.12 & 1.85 \\
$\mathrm{G}_{\mathrm{c}}[\mathrm{N} / \mathrm{mm}]$ & 4.8 & 5 \\
\hline \hline$\beta$ & 0.01 & 0.01 \\
\hline \hline
\end{tabular}

Table 7: Mechanical parameter for masonry type (SB: stone blocks; HCB: hollow clay bricks).

The values for the connections' stiffness were analytically identified according to the European regulations for steel-to-timber fasteners and connectors [18]. As the project did not provide for any connection between the masonry walls and the CLT panels, the 3D surface interface elements were not considered, likewise the layout in [4]. At last, non-linearities were located in the masonry material model only.

Modal and pushover analyses were performed on the URM and the URM-CLT models. Uniform loads in both principal directions were considered for pushover analysis.

\subsection{Results}

The modal analyses results (Table 8) showed an increase in modal frequencies due to nesting intervention, partly due to the decrease of total mass for the reinforced model (about $25 \%$ ). The modal participation mass factor also decreases to around $65 \%$ for the first two bending modes, in each principal direction. This could be due to the difference in terms of masses and stiffnesses distributions generated by the presence of the endoskeleton only at the second and third floors, whereas the first one remained unchanged.

\begin{tabular}{c|ccc|ccc}
\hline \multirow{2}{*}{ Mode } & \multicolumn{3}{|c|}{ URM model } & \multicolumn{3}{c}{ Reinforced model } \\
\cline { 2 - 7 } & $\mathrm{f}[\mathrm{Hz}]$ & $\% \mathrm{mx}$ & $\% \mathrm{my}$ & $\mathrm{f}[\mathrm{Hz}]$ & $\% \mathrm{mx}$ & $\% \mathrm{my}$ \\
\hline 1 & 6.147 & $0.00 \%$ & $75.55 \%$ & 7.298 & $0.09 \%$ & $66.89 \%$ \\
2 & 8.052 & $76.15 \%$ & $0.00 \%$ & 8.491 & $65.66 \%$ & $0.10 \%$ \\
3 & 9.787 & $2.21 \%$ & $0.01 \%$ & 10.845 & $0.56 \%$ & $0.01 \%$ \\
\hline
\end{tabular}

Table 8: Frequencies and mass participation factors for the first three modes: URM and reinforced (URM+CLT) models.

Pushover analyses results were evaluated in terms of equivalent acceleration at the base, thus normalizing the results to the mass of the model to obtain comparable curves (Figure 10). This comparison shows an increase in maximum equivalent acceleration for the retrofitted model. Differences were more pronounced for Y direction analyses than X direction's ones; this suggests that the intervention could be more effective on the shear capacity of the weaker direction. Ultimate displacement capacity does not get significantly affected instead. 

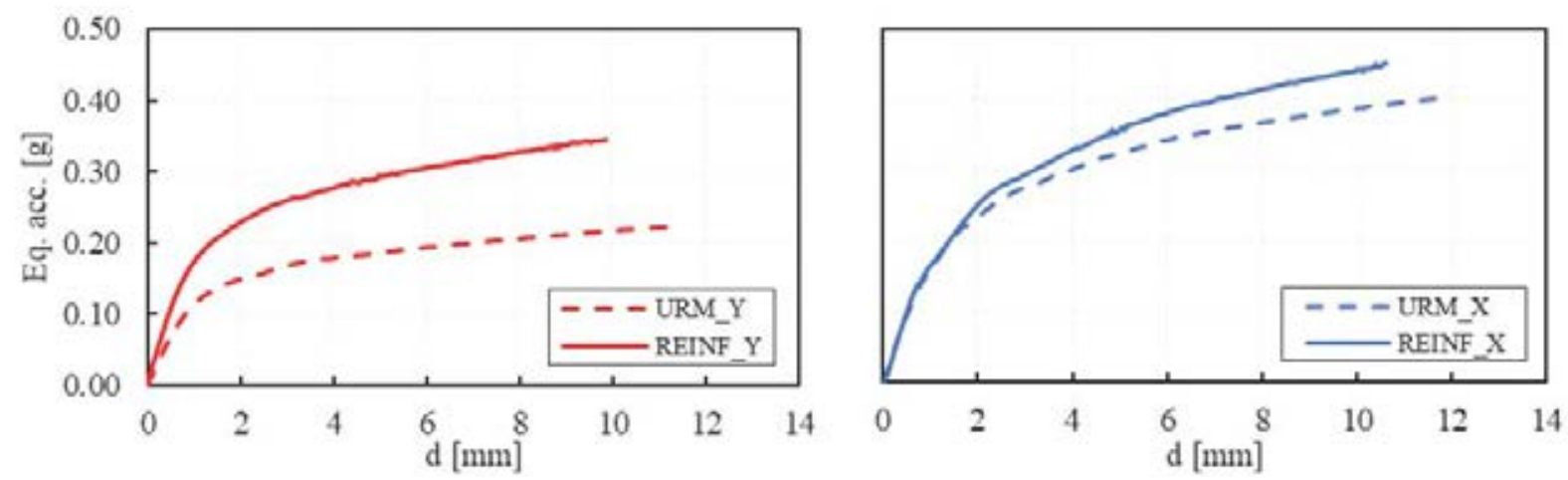

Figure 10: Pushover curves for X e Y directions analyses

Further observations can be made from the contour of tensile strain, where cracks should rise. On the URM model (Figure 11a), damage is mainly located on the piers of the ground floor, while upper levels are less damaged. With the intervention (Figure 11b), the damage involves all stories, thus exploiting the resistant elements along the entire height. Moreover, in the URM model, tensile strains significantly spread in piers and lintels, whereas in the URMCLT model strains are lumped in piers, i.e., the resistant elements of masonry structures.

[a]
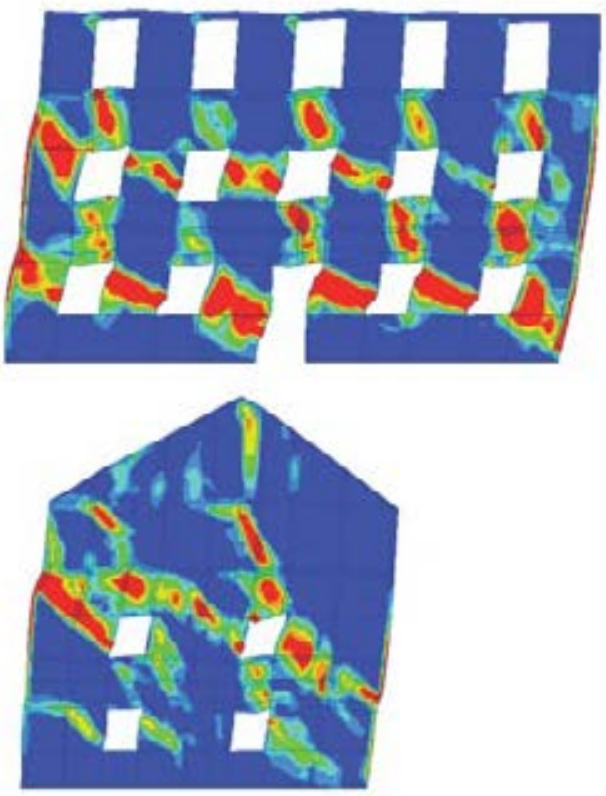

[b]
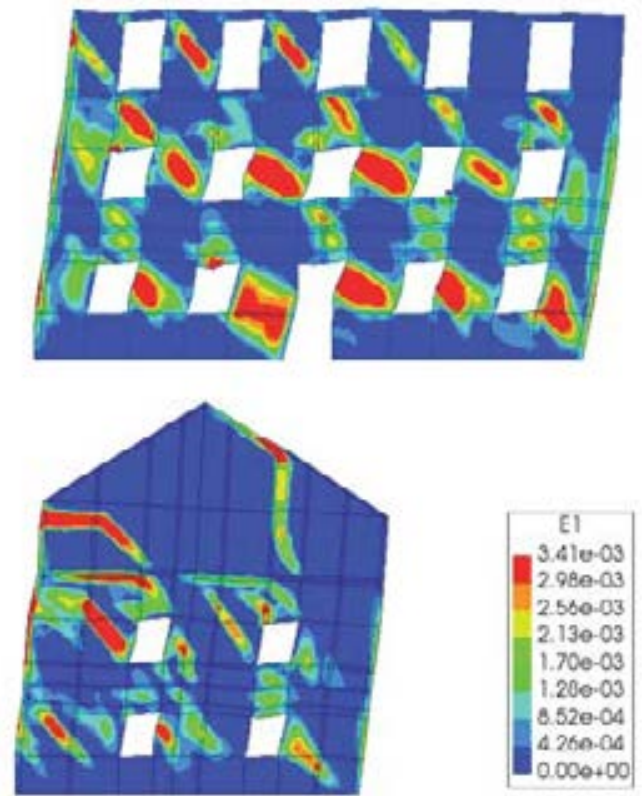

Figure 11: Damage patterns for a) URM and b) retrofitted models.

At last, to measure the intervention benefits, seismic safety verifications were carried out according to the Italian code [19], by comparing PGA (peak ground acceleration) values for derived from the capacity curves. The results showed an improvement on the global behavior of the building thanks to the intervention, with an increase of $+8.6 \%$ and $+19.8 \%$ in $\mathrm{X}$ and $\mathrm{Y}$ directions, respectively (Table 9). Further improvements can be obtained, taking into consideration that, currently: i) the intervention is lumped at second and third stories, whereas the first one is the most solicited by uniform mass distribution and, ii) no improving interventions such as injections or joints rebars were adopted for masonry walls. 


\begin{tabular}{cccc}
\cline { 2 - 3 } & \multicolumn{2}{c}{ URM } & \multicolumn{2}{c}{ URM+CLT } & \\
\cline { 2 - 4 } Direction & PGA $_{\mathrm{C}}[\mathrm{g}]$ & PGAC $_{\mathrm{C}}[\mathrm{g}]$ & $\Delta$ PGA $_{\mathrm{C}}[\%]$ \\
\hline$+\mathrm{X}$ & 0.222 & 0.241 & $8.6 \%$ \\
$+\mathrm{Y}$ & 0.187 & 0.224 & $19.8 \%$ \\
\hline
\end{tabular}

Table 9: Near-collapse PGA capacities $\left(\mathrm{PGA}_{\mathrm{C}}\right)$ and percentage variation between un-strengthened and retrofitted cases.

\section{CONCLUSIONS}

The modelling of a novel intervention technique for URM buildings was discussed in this paper. The study was carried out both at local and overall scale. The local model, on which parametric analyses were performed showed that:

- the CLT reinforcement is effective on the post-elastic phase of masonry, when cracking occurs and cause a loss in masonry stiffness;

- the timber connections (i.e., hold-down and angle brackets) play a fundamental role in the effectiveness of the system, since they affect its stiffness more than CLT panel thickness.

The local FE model allowed the connections of timber (both panel-to-panel and floor-topanel) to be calibrated and to be implemented within a global FE model of an existing URM building. Modal and pushover analyses were carried out, on both as-built and retrofitted models. Results suggested that:

- mass reduction due to substitution of RC floors with lighter timber panels induced the increment in mode frequencies;

- retrofitted configuration can bear a higher equivalent acceleration than as-built one;

- the intervention led to a more homogeneous damage pattern, involving more resistant elements than the un-strengthened case;

- the intervention was effective, taking into consideration that it is limited to the second and third floor (demolition of two RC floors and RC roof), and provided an improvement in terms of PGAC up to $20 \%$.

The results showed that the CLT endoskeleton proposed here is a promising technique to improve the seismic performances of URM buildings. However, further studies need to be carried out to better clarify the effectiveness of the intervention and to extend its field of application.

\section{ACKNOWLEDGEMENTS}

This work was supported by the CORE-WOOD (COmpetitive REpositioning of WOOD sector) Italian project, in the framework of POR-FESR 2014-2020 Line 1 Action 1.1.4 of the Veneto Region.

\section{REFERENCES}

[1] F. Celano, M. Cimmino, O. Coppola, G. Magliulo, P. Salzano, Report dei danni registrati a seguito del terremoto del Centro Italia del 24 Agosto 2016, Reluis Report (Release 1), 2016, [Online]. Available: http://www.reluis.it. (in Italian) 
[2] R. Cardoso, M. Lopes, R. Bento, Earthquake Resistant Structures of Portuguese Old 'Pombalino' Buildings, 13th World Conference Earthquake Engineering Vancouver, B.C., Canada, 918, 2004.

[3] S. Tonna, N. Ruggieri, C. Chesi, Comparison between Two Traditional EarthquakeProof Solutions: Borbone and Lefkada Timber-Frame Systems, Journal of Architectural Engineering, 24, 4, 2018.

[4] L. Pozza, L. Marchi, D. Trutalli, R. Scotta, In-plane strengthening of masonry buildings with timber panels, Proceedings of the Institution of Civil Engineers - Structures and Buildings, 1-15, 2021. https://doi.org/10.1680/jstbu.19.00121.

[5] L. Pozza, F. Evangelista, R. Scotta, CLT used as seismic strengthener for existing masonry walls, Atti del XVII convegno ANIDIS L'Ingegneria sismica in Italia, pp. 210$220,2017$.

[6] M.R. Valluzzi, E. Saler, A. Vignato, M. Salvalaggio, G. Croatto, G. Dorigatti, U. Turrini, Nested buildings: An innovative strategy for the integrated seismic and energy retrofit of existing masonry buildings with CLT panels, Sustainability 13, 1-19, 2021. https://doi.org/10.3390/su13031188.

[7] R. Scotta, D. Trutalli, L. Marchi, L. Pozza, Seismic performance of URM buildings with in-plane non-stiffened and stiffened timber floors, Engineering Structures, 167, 683-694, 2018. https://doi.org/10.1016/j.engstruct.2018.02.060.

[8] TNO Building and Construction Research, DIANA - Finite Element Analysis User's Manual - Release 10.4, 2020

[9] M. Salvalaggio, L. Sbrogiò, M. Pavanetto, M.R. Valluzzi, Evaluation of the effect of compatible interventions applied to horizontal components of URM buildings with EFM and FEM models. The case of palazzo Carraro in Noale (Italy), COMPDYN Proc. 1 (2019) 1472-1481. https://doi.org/10.7712/120119.7012.19513.

[10] I. Giongo, G. Schiro, M. Piazza, On the Use of Timber-Based Panels for the Seismic Retrofit of Masonry Structures, 3rd Int. Conf. on Protection of Historical Construction, pp. 12-15, 2017.

[11] S. Churilov, E. Dumova-Jovanoska, In-plane shear behaviour of unreinforced and jacketed brick masonry walls, Soil Dynamics and Earthquake Engineering, 50, 85-105, 2013. https://doi.org/10.1016/j.soildyn.2013.03.006.

[12] TimberTech, TimberTech Buildings, ver.77.

[13] J.M. Branco, M. Kekeliak, P.B. Lourenço, In-plane stiffness of timber floors strengthened with CLT, Eur. J. Wood Wood Prod. 73, 313-323, 2015. https://doi.org/10.1007/s00107-015-0892-2.

[14] I. Sustersic, B. Dujic, Seismic Strengthening of Existing Concrete and Masonry Buildings with Crosslam Timber Panels, Materials and Joints in Timber Structures, 713-723, 2014. 
[15] A. Lucchini, E. S. Mazzucchelli, S. Mangialardo, M. Persello, Façadism and Clt Technology: an Innovative System for Masonry Construction Refurbishment, 40th IAHS World Congress Hous., December 2014.

[16] D. Riccadonna, I. Giongo, G. Schiro, E. Rizzi, M. A. Parisi, Experimental shear testing of timber-masonry dry connections for the seismic retrofit of unreinforced masonry shear walls, Construction and Building Materials, vol. 211, 52-72, 2019.

[17] P. B. Lourenço, "Structural Masonry Analysis: Recent Developments and Prospects," J. Chem. Inf. Model., vol. 53, no. 2004, p. 160, 2008.

[18] European Committee for Standardization, "Eurocode 5: Design of Timber Structure" BSI, 1994.

[19] C.S.LL.PP, Circolare 21 gennaio 2019, n. 7, "Circolare applicativa delle nuove Norme Tecniche per le Costruzioni approvate con D.M. 17 gennaio 2018”, 2019. (In Italian)

[20] Ministero delle Infrastrutture e dei Trasporti, D.M. 17 gennaio 2018, "Aggiornamento delle «Norme tecniche per le Costruzioni»", 2018. (in Italian)

[21] A. Borri, A. De Maria, Indice di Qualità Muraria (IQM): correlazione con le caratteristiche meccaniche e livelli di conoscenza, ReLuis 2015 - Linea Costruzioni in. Muratura, 45-63, 2015. (in Italian)

[22] L. Bejarano-Urrego, E. Verstrynge, G. Giardina, K. Van Balen, Crack growth in masonry: Numerical analysis and sensitivity study for discrete and smeared crack modelling, Engineering Structures, 165, 471-485, 2018. 